\title{
HIBERNATING BAT SPECIES OF BELARUS: RESULTS OF THE WORK OF THE MINSK BAT CONTACT CENTRE
}

\author{
Aliaksei Shpak \\ The Scientific and Practical Center for Bioresources (Minsk, Belarus) \\ Correspondence to: A. Shpak; Scientific and Practical Center for Bioresources, NAS of Belarus; \\ Akademičnaja St.27, Minsk, 220072 Belarus; e-mail: shpak.dvergr@gmail.com
}

\begin{abstract}
Hibernating bat species of Belarus: results of the work of the Minsk bat contact centre. - A. Shpak. Bat contact centres are organizations that exist in a number of countries and are engaged in popularization work, informational support for people facing bats, as well as rehabilitation and temporary maintenance of animals threatened with death during hibernation period. The data obtained during the activity of Minsk batcontact centre during winter periods of 2007-2016 are presented in the article. In total, 108 hibernating specimens and 5 colonies of 6 species ( $V$. murinus, $N$. noctula, E. nilssonii, E. serotinus, P. auritus, and $P$. kuhlii) were registered for 18 localities of Belarus. The dominant among the registered hibernating bats is $V$. murinus. At the same time, the expansion of the wintering range is shown for V. murinus, $N$. noctula, and P. kuhlii. The dynamics of the species registrations during the period of the activity of the Centre, as well as during the period of hibernation, are presented. The results of the Centre's work show the high efficiency of such organizations for the monitoring of fauna and accumulation of scientific information.
\end{abstract}

Key words: bats, hibernation, range expansion, contact centre, Belarus.

\begin{abstract}
Зимуючі види кажанів Білорусі: підсумки роботи Мінського контакт-центру. - О. Шпак. Контакт-центри по кажанам - товариства, які існують у низці країн і займаються популяризацією та інформуванням людей, які зіштовхнулися з рукокрилими, а також реабілітацією та зимовим утримуванням тварин, що знаходяться під загрозою загибелі впродовж гібернаційного періоду. У статті наведено дані, отримані Мінським контакт-центром щодо рукокрилим впродовж 2007-2017 рр. Всього відмічено 108 зимуючих особин та 5 колоній кажанів 6 видів (V. murinus, N. noctula, E. nilssonii, E. serotinus, $P$. auritus, $P$. kuhlii) з 18 населених пунктів Білорусії. Домінуючим у структурі зимуючих видів $\epsilon$ лилик двоколірний. В той же час відмічено розширення зимівельного ареалу для трьох видів V. murinus, N. noctula та P. kuhlii. Наведено як багаторічну, так і сезонну динаміку реєстрації тварин. Результати роботи Центру демонструють високу ефективність подібних центрів у моніторингу фауни і накопиченню наукової інформації.
\end{abstract}

Ключові слова: кажани, зимівля, розширення ареалу, контакт центр, Білорусь.

\section{Introduction}

Bats (Chiroptera) are an order of mammals, which due to the specifics of their biology strongly depend on humans. In particular, bats can use human buildings as temporary or permanent roosts (Voight, 2016). In such case, often there is an animal-human conflict, which usually leads either to the exilement of animals from the roost or to their death (Merzlikin, 2002). However, bats are legally protected in most countries of Europe (Council Directive 92/43/EEC, Bonn and Bern Conventions). In Belarus, particularly, eight bat species are included into the national Red Data Book (2016 ed.).

Solving this problem solely through the popularization and distribution of knowledge about bats is not always possible for a number of reasons. At the best, finding of wintering or maternity colonies during private or department repair and construction works ends with appealing of the people who discovered the colony to a specialized nature protection organization (e.g., Ministry of Natural Resources, City Committee of Natural Resources, State Inspectorate for the Protection of Flora and Fauna), to the Ministry for Emergency Situations, or to NGO "APB-Birdlife Belarus." 
Usually, all reports are redirected to the Academy of Sciences. In any case, animals are expelled from the roosts and, if the situation takes place during hibernation period, they need rehabilitation. Although, firstly, the rehabilitation of bats cannot be provided by the resources of the mentioned organizations and, secondly, it is not among their goals. There is a similar situation, when hibernating bats are found on balconies, in entrances, office rooms, etc., with the only difference that, in this case, occasionally it is possible to leave the animal in the roost without disturbing it.

Obviously, specialized contact and rehabilitation centres for bats, which goals are rehabilitation of animals and popularization work, should deal with such problems. In addition, the indirect result of the work of such centres is the constant accumulation of scientific information and monitoring of the bat fauna (Godlevska, 2012). This is all the more topical because systematic assessment of species composition of wintering bat for the whole territory of Belarus has not been carried out since the 1980s. Thus, the main goal of this work is the refinement of the current species composition of bats, wintering in Belarus, and clarification of some of their ecological features.

\section{Material and methods}

The data presented here are the result of the work of the Minsk bat contact centre in the period from 2007 to 2017. The activity of the Centre from 2007 to 2012 was rather sporadic, becoming regular only in the following years (2012-2016), when the number of requests for animal finds increased sharply (fig. 1). In our opinion, this is due to the number of educational events in 2012, dedicated to the International Year of Bats and their implementation into regular annual practice with media coverage. In addition, it should be noted that upon detection of animal the source of information on the activity of the Centre is mainly the Internet or the above-mentioned environmental organizations and NGO.

The work of the Centre is mainly to provide information support to people, who have applied upon detection of bats. If the animals could not be left in their original roost (finds on the street, on balconies and in living quarters, during construction works, etc.), bats were accepted by the Centre for rehabilitation and artificial hibernation with subsequent release into the nature. Captured animals were examined for species identification, trauma detection and registration of basic morphometric parameters. In some cases, species identification was done according to the provided photos. All the information received was added to the database with the following sections: species, date, sex, age, length of forearm, weight, place of registration, details, further fate, name of the person applying, his/her phone number, source of information about the Centre, and photo of the animal (if possible). According to the literature data (Kurskov, 1981), all bats found between 1 October and 30 April were considered hibernating. However, there is a possibility that the individuals registered in the beginning of October or second half of April were migrants.

\section{Results}

In total, from the XIX century to the present day, the hibernation of 12 bat species was registered in Belarus:

Myotis dasycneme (Boie, 1825), M. daubentonii (Kuhl, 1817), M. mystacinus (Kuhl, 1817), M. nattereri (Kuhl, 1817), Plecotus auritus Linnaeus, 1758, P. austriacus (Fischer, 1829), Barbastella barbastellus (Schreber, 1774), Nyctalus noctula (Schreber, 1774), Pipistrellus kuhlii (Kuhl, 1817), Eptesicus serotinus Schreber, 1774, E. nilssonii (Keyserling et Blasius, 1839), and Vespertilio murinus Linnaeus, 1758 (Shpak, 2017).

Because of the Centre's activity, the hibernation of 6 bat species was noted, the details of which are given below. Due to the specifics of the Centre's work, all finds in different settlements (cities, villages etc.) were registered. However, given that there are no natural underground roosts in Belarus and hibernation in tree hollows and similar roosts is impossible due to their freezing in winter (Kuzyakin, 1936), the facts of hibernation of bats in the modern period are registered in anthropogenic roosts with a few exceptions (Kurskov 1981; Demyanchyk, 2001; V. Grichik, pers. comm.). 

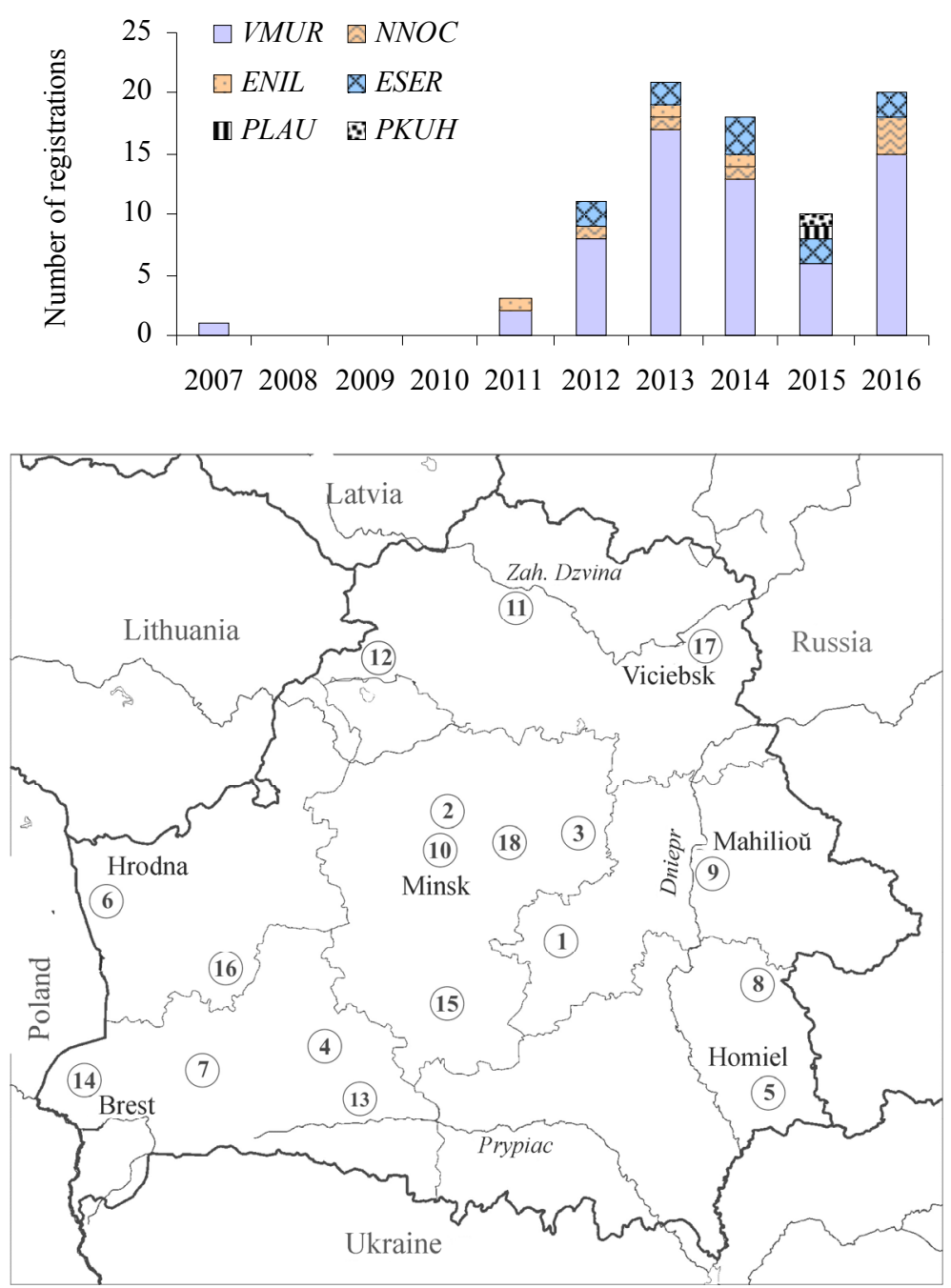

Fig. 1. Dynamics of hibernating bats' registration during 2007-2017.

Рис. 1. Динаміка реєстрацій зимуючих кажанів протягом 2007$2017 \mathrm{pp}$.

Fig. 2. Localities of finds of wintering bats in Belarus.

Рис. 2. Місцезнаходження зимуючих кажанів в Білорусі.

1. Asipovičy, 2. Baraŭliany, 3. Barysaŭ, 4. Cieliachany, 5. Homiel, 6. Hrodna, 7. Jastrabiel, 8. Karma, 9. Mahileŭ, 10. Minsk, 11. Navapolack, 12. Pastavy, 13. Pinsk, 14. Ratajčycy, 15. Salihorsk, 16. Slonim, 17. Viciebsk, 18. Žodzina.

In total, 113 requests from 16 localities of Belarus were received during the described period (fig. 2). Among them, 5 appeals concerned with finds of bat aggregations and 108 with records of single individuals. All finds are described in the text according to the following scheme: Single individuals and photo registrations: sex (F - female, $\mathrm{M}$ - male, ? - unidentified), date (dd.mm.yy), details; Colonies: date, details. Species in the list below are in the order of decreasing the number of registrations.

\section{Vespertilio murinus}

There are 76 finds ( 73 single specimens +3 colonies) from 8 localities, which is $70.3 \%$ of the total number of records.

A sipovičy, single specimens, photo record: sex?, 09.12.2017, found in the mail box.

Barysaŭ, single specimens, photo record: sex?, 05.10.2016, found grounded; sex?, 11.12.2016, found grounded.

Homiel, single specimens, contact record: F, 27.01.2011, flew into the window of a multi-storey building (V. V. Gritchik, pers. com).

Minsk, single specimens, contact records: M, 01.11.2007, flew into the air conditioner tube of an office room; M, 28.10.2008, balcony on the 7th floor; M, 30.11.2008, balcony on the 5th floor; M, 17.11.2010, balcony on the 8th floor; M, 13.11.2011, balcony on the 6th floor; F, 27.09.2012, found grounded near a multi-storey building; M, 20.10.2012, inside an office room; M, 25.10.2012, found in a wood-frame win- 
dow, 11th floor; F, 26.10.2012, found grounded near a multi-storey building; F, 01.11.2012, flew into a window, 11th floor; M, 05.11.2012, details are unknown; M, 12.11.2012, 5th floor; M, 23.11.2012, found in a wood-frame window, 1st floor of a multi-storey building; M, 22.12.2012, multi-storey building; M, 04.01.2013, inside a multi-storey building; M, 05.01.2013, inside a multi-storey building; M, 05.01.2013, balcony on the 9th floor; F, 14.01.2013, inside a multi-storey building; F, 20.01.2013, inside a multistorey building; F, 30.01.2013, found between the glasses of a window frame, 4th floor of a multi-storey building; F, 31.01.2013, inside a multi-storey building; M, 06.03.2013, balcony on the 9th floor; M, 07.03.2013, inside a multi-storey building; M, 11.03.2013, details are unknown; M, 11.04.2013, details are unknown; M, 29.11.2013., found in a wood-frame window, 9th floor of a multi-storey building; F, 17.01.2014, balcony on the 10th floor; F, 20.01.2014, found in a wood-frame window; M, 30.01.2014, found in a wood-frame window, 4th floor; F, 03.02.2014, flew in the stairwell of a multi-storey building; $\mathrm{F}, 03.02 .2014$, flew in the stairwell of a multi-storey building; F 18.04.2014, multi-storey building, flew out of the elevator shaft, 3-4 finds before; F 30.10.2014, stairwell, 8th floor of a multi-storey building; F, 18.11.2014, stairwell of a multi-storey building; M 24.11.2014, flew into an apartment on the 10th floor; F 03.12.2014, found in an apartment, multi-storey building; M 30.12.2014, multi-storey building; F 25.09.2015, balcony on a multi-storey building; F 02.10 .2015 , found grounded near a multi-storey building; M 12.10.2015, found grounded near a multi-storey building; F 26.10.2015, found on the windowsill, 20th floor; M 07.12.2015, flew into a balcony; F 08.12.2015; F 11.12.2015, found in the stairwell, multistorey building; F 23.01.2016, found in the stairwell, multi-storey building; M, F, 09.02.2016, found in the same stairwell, multi-storey building; F, 18.10.2016, flew into an office room, multi-storey building; M, 08.11.2016, flew into an apartment, multi-storey building; M, 29.11.2016, found in the stairwell, multistorey building; F, 05.12.2016, found in the stairwell, multi-storey building; M, 15.12.2016, found in the stairwell, multi-storey building; F, 16.12.2016, found in the apartment, multi-storey building; F, 27.12.2016, details are unknown; F, 17.10.2017, found grounded; sex?, 08.11.2017, F, found grounded; M, 09.12.2017, found in an apartment, multi-storey building; F, 09.12.2017, found in an apartment, multistorey building; M, 11.12.2017, flew into an apartment on the 7th floor.

Photo records: sex?, 23.11.2012, flew into an apartment on the 7th floor; sex?, 07.12.2012, balcony of a multi-storey building; sex?, 07.10.2013, found grounded; sex?, 28.10.2013, flew into the window of a multi-storey building; sex?, 08.11.2013 found in a wood-frame window, 6th floor of a multi-storey building; sex?, 01.10.2016, found grounded; sex?, 20.10.2017, found in an apartment, multi-storey building.

Colonies: 14.11.2012, about 30 specimens flew into the window of a multi-storey building; 24.12.2015, colony (more than 10 individuals) was found behind the old windows of the plant (Minsk Mechanical Works named after S. I. Vavilov), two females were caught; 22.02.2016, several individuals were flying in the stairwell, one male was caught.

Navapolack, single specimens, photo record: sex?, 21.02.2017, found in the stairwell, multi-storey building.

Pastavy, single specimens, photo record: sex?, 13.12.2013, flew into apartments on the 6th floor through the vent hole.

Pinsk, single specimens, photo record: sex?, 19.10.2016, found grounded.

Salihorsk, single specimens, photo record: 11.10.2017, found under the signboard.

The parti-coloured bat was considered in Belarus as a migrant species until recently. This point of view was based on the absence of winter records, as well as the registrations in Austria and Romania of two specimens, banded in Belarus. The data obtained over the past few years allow stating that the whole territory of Belarus belongs to the wintering range of this species. Hibernation of V. murinus in Belarus is described in detail in our previous article (Shpak, 2016). Vespertilio muri$n u s$ is the apparent dominant among our finds ( $70.3 \%$ of the total number of registrations), of which 3 concerned colonies and 73 were single individuals.

The dominance of $V$. murinus can be explained by several reasons:

- the real prevalence among hibernating bat species;

- as hibernating roosts, $V$. murinus uses caves, tunnels, underground structures, and high buildings, which are equivalent to natural roosts in urban landscapes and thus it belongs to the group of epilithic species (Klausnitzer, 1987). As mentioned above, the number of educational events, such as annual International Bat Nights, excursions, interviews etc. are held since 2012. Mostly, these events take place in either Minsk or other cities. Due to this factor, most of the requests to 
the Centre come from medium-sized or large cities and, therefore, our data may reflect the species composition of such habitats;

- possible greater sensitivity of the parti-coloured bat to the winter temperature changes and anxiety in general, which leads to the fact that it leaves the hibernation roost and attracts people's attention.

\section{Eptesicus serotinus}

There are 17 finds (17 single specimens) from 5 localities, which is $15.7 \%$ of the total records.

Minsk, single specimens, contact records: F, 15.10.2012, found grounded; F, 18.12.2012, found on the wall outside; F, 28.10.2013, found grounded; F, 03.01.2014, found dead on the wall inside a multi-storey building; M, 27.11.2014, flew into a multi-storey building; M, 19.02.2015, found dead, multi-storey building; F, 01.12.2015, found grounded; M, 05.01.2016, found grounded; M, 09.01.2017, found grounded; M, 24.01.2017, found in the toilet of the Central Botanical Garden; F, 21.02.2017, found under a drainpipe Photo records: sex?, 23.12.2013, flew into a cottage;

Homiel, single specimens, photo record: sex?, 31.12.2014, found grounded; M, 04.01.2017, found grounded.

Pinsk, single specimen, photo record: sex?, 11.04.2017, flew into a car.

Salihorsk, single specimen, photo record: sex?, 14.10.2016, found grounded.

Slonim, single specimen, photo record: sex?, 12.03.2017, found on the floor of a garage.

The serotine bat is a sedentary species. The facts of its hibernation in Belarus has been noted since 1940 (Serzhanin, 1955). The same situation is observed in the whole European part of its range, where the recorded distance between summer and winter roosts is usually less than $40-50 \mathrm{~km}$ (Baagoe, 2001).

\section{Nyctalus noctula}

There are 12 finds (10 single specimens +2 colony) from 7 localities, which is $11.1 \%$ of the total records.

Ho miel, single specimen, photo record: sex?, 16.02.2017, found grounded.

Hrodna, single specimen, contact record: M, 09.01.2017, details are unknown.

Photo record: sex?, 28.03.2017, flew over the river.

Jastrabiel village (vicinities), Stolin district, Brest region, colony, 25.10.2010, 22 individuals, a hollow on a grey alder (Alnus incana (L.) Moench, 1794). Two females were caught (V. V. Gritchik, pers. com.).

Mahileŭ, single specimens, photo records: sex?, 20.04.2014, balcony, multi-storey building.

Minsk, single specimens, contact records: M, 07.12.2012, balcony, multi-storey building; M, 04.04. 2013, balcony, multi-storey building; F, 30.11.2016, found grounded; F, 05.12.2016, found grounded.

Salihorsk, single specimen, photo record: sex?, 01.03.2017, found grounded. Colony, photo record: 25.04.2016, more than 30 individuals, under window space. It was also found a lot of faeces and several mummified specimens.

Žodzina, single specimens, contact records: M, 21.11.16, found in the stairwell, multi-storey building.

The noctule bat is a widespread species, considered for Belarus as a migrant, and it was confirmed by banding data. The terms of the spring arrival extended from the end of April for western Belarus to the second half of May for the eastern part of the country. Recent data (Godlevska, 2014) show the expansion of wintering range of $N$. noctula in the northeastern direction since the 1990s. Until now, this range is expanding in the territory of Poland, Ukraine and southwestern Russia. The facts of the noctule bat hibernation have been noted for southwestern Belarus since the late 1990s (Demianchyk, 2001). Our finds allow expanding the boundaries of the wintering range of N. noctula in the northeast direction, thereby confirming the assumptions of L. Godlevska (2014). However,

- permanent hibernation roosts were not found yet,

- mainly, single individuals were registered during hibernation period.

We suppose, that there are just attempts of hibernation take place in Belarus at the present time. 


\section{Eptesicus nilssonii}

There are 3 finds ( 3 single specimens) from 3 localities, which is $2.7 \%$ of the total records.

Baraŭliany, single specimens, photo record: sex?, 13.10.2013, found grounded.

Minsk, single specimens, contact record: $\mathrm{M}, 08.12 .2011$, found on the outside windowsill, $5^{\text {th }}$ floor, multi-storey building;

Viciebsk, single specimens, photo record: sex?, 21.01.2014, found on the factory floor.

The northern bat is a rare species of the Belarusian bat fauna and it is included into the Red Data Book of Belarus and has IV category (NT) of the national nature conservation significance. Based on the absence of winter finds, Kurskov (1981) described this species as a migrant. The first registrations of E. nilssonii during hibernation period were noted in Brest in 1996-1997 (Demianchyk, 2001). Our finds of single individuals in three locations in central and northern Belarus make possible to consider this species as wintering.

\section{Plecotus auritus}

There are 3 finds ( 3 single specimens) from 3 localities, which is $2.7 \%$ of the total records.

Cielia chany, Brest region, single specimen, photo record: sex?, 10.02.2015, hibernation, cellar.

Mahileu, single specimen, photo record: sex?, 29.04.2017, found on the balcony.

Ratajčycy village, Kamianec district, Brest region, single specimen, photo record: sex?, 26.01.2014, hibernation, cellar.

This bat is a widespread species, which is sedentary in the whole area of its range. The maximum documented distance of its seasonal movements is $90 \mathrm{~km}$ (Hutterer et al., 2005).

\section{Pipistrellus kuhlii}

There are 2 finds ( 2 single specimens) from 2 localities, which is $1.8 \%$ of the total records.

Karma, Homiel region, single specimen, photo record: sex?, 10.11.2015, found during renovation behind a downspout of a five-storey building.

Minsk, single specimens, contact records: M, 30.01.2017, found in the stairwell of a multi-storey building.

In Belarus, the first winter colony of Kuhl's pipistrelle bat was registered in 2012 (Demianchyk, 2013) in the Brest region and it was the first ever registration of this species. During 2015-2016, there were two finds of single individuals to North and Northeast from the original locality. This limits all information about biology and distribution of $P$. kuhlii in Belarus. In our previous article (Shpak, Larchanka, 2017), the character of the expansion of this species from the middle of the 1980 s to the present time was analysed. It was suggested that the colonization of the territory of Belarus occurred, mainly, from the Eastern centre of the species' distribution (Azerbaijan) and range expansion will take place in northwest direction along rivers of the Dnieper and Prypiac basins.

\section{Discussion}

It should be noted, that there are no finds of Myotis and Barbastella genera. The absence of representatives of the genus Barbastella can be explained by the fact that the border of the wintering range passes through the West of Belarus, where the fortifications of Brest Fortress are the largest hibernation site. We suppose that the absence of representatives of the genus Myotis may be related to their relative rarity: four of the six species registered in Belarus (M. dasycneme, M. nattereri, M. brandtii, M. mystacinus) have a high level of national conservationl significance and are included into the Red Data Book of Belarus (2016). Besides, M. myotis has not been recorded since 1970.

The number of requests related to findings of wintering animals is approximately at the same level from October to January, reaching a slight peak in December and gradually declining from February to April (fig. 3). 


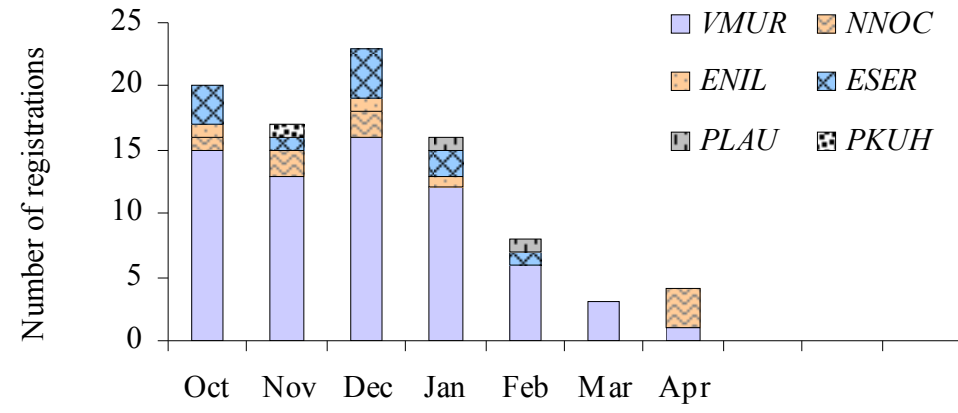

Fig. 3. Dynamics of species and individual numbers during hibernation period.

Рис. 3. Динаміка числа зареєстрованих видів та кількості їх особин протягом зимівлі.

The sample's size does not allow us conducting reliable statistical analysis, but gives grounds to assume that the decrease in the number of finds in the second half of winter and the beginning of spring may be due to the death of a significant number of animals because of depletion of energy reserves during forced winter activity. Here should be noted that many animals were found during the anomalous winter activity - they flew into apartments, entrances, were found on the ground.

\section{Acknowledgements}

We thank to V. V. Gritchik for his kindness to provide data on his finds of N. noctula, A. Larchanka and A. Ziankevich for their help in catching of the animals. We also are very grateful to both anonymous peer-reviewers, whose remarks greatly improved the quality of the manuscript.

\section{References • Література}

Baagøe, H. J. 2001. Vespertilio murinus Linnaeus, 1758. In: Krapp, F., J. Niethammer (eds). Handbuch der Säugetiere Europas. Band 4. Fledertiere Teil. Wiebelsheim, 473-514.

Demianchyk, M. G. 2001. First winter records of the northern bat (Eptesicus nilssonii) and the noctule bat (Nyctalus noctula) on the territory of Belarus. Diversity of the Animal World of Belarus. Proc. Intern. Sci. Conf. (28-30 November 2001). Minsk, 174-176. (In Russian)

[Демянчик, М. Г. 2001. Первые зимовки кожанка северного (Eptesicus nilssonii) и вечерницы рыжей (Nyctalus noctula) на территории Беларуси. Разнообразие животного мира Беларуси. Материалы Междунар. научн. конф. (28-30 ноября 2001. Минск, 174-176.]

Demianchyk, V. V. 2013. Faunal complexes of vertebrates in human settlements of Prypiac Palesse. The Rational Use of Flood Plains. Minsk, 98-102. (In Russian)

[Демянчик, В. В. 2013. Фаунистические комплексы позвоночных животных населенных пунктов Припятского Полесья. Раи. использ. поймен. земель. Минск, 98-102.]

Godlevska, L V. 2012. Results of the work of the bat contactcentre (Ukraine). Scientific Notes of Taurida V. I. Vernadsky National University. Series: Biology, chemistry, 25 (64), No. 4: 12-20. (In Russian)

[Годлевская, Е. В. 2012. Результаты работы контактцентра по рукокрылым (Украина). Ученые записки Таврического наи. ун-та им. В. И. Вернадского. Серия Биология, хииия, 25 (64), № 4: 12-20.]

Godlevska, L. 2015. Northward expansion of the winter range of Nyctalus noctula (Chiroptera: Vespertilionidae) in Eastern Europe. Mammalia, 79 (3): 315-324.

Hutterer, R., T. Ivanova, C. Meyer-Cords, L. Rodrigues. 2005. Bat migrations in Europe: A review of literature and analysis of banding data. Naturschutz und Bilologische Vielfalt, 28: $1-176$.
Klausnitzer, B. 1987. Ökologie der Großstadtfauna. Jena, 1225.

Kurskov, A. N. 1981. Bats of Belarus. Minsk, 1-135. (In Russian)

[Курсков, А. Н. 1981. Рукокрылые Белоруссии. Минск, 1135.]

Kuzyakin, A. P. 1936. Living conditions of animals in tree hollows. Air temperature in hollows. Problems of Ecology and Biocenology. Vol. 3. Moskva, 266-273. (In Russian)

[Кузякин, А. П. 1936. Условия обитания животных в дуплах деревьев. Температура воздуха в дуплах. Bonросы экологии и биоченологии. Bып. 3. Москва, 266-273.]

Merzlikin, I. R. 2002. On some causes of bat mortality in Sumy region (Northeastern Ukraine). Plecotus et al. Pars spec., 113-115. (In Russian)

[Мерзликин, И. Р. 2002. О некоторых причинах гибели рукокрылых в Сумской области (северо-восточная Украина). Plecotus et al. Pars spec., 113-115.]

Serzhanin, I. N. 1961. Mammals of Byelorussian SSR. Minsk, 1-317. (In Russian)

[Сержанин, И. Н. 1961. Млекопитающие Белорусской ССР. Минск, 1-317.]

Shpak, A., A. Larchanka. 2016. Range expansion of Kuhl's pipistrelle (Pipistrellus kuhlii) into Belarus. Proceedings of the Theriological School, 14: 99-102.

Shpak, A. 2017. Hibernation of Parti-coloured bat, Vespertilio murinus (Chiroptera, Vespertilionidae), in Belarus. Vestnik zoologii, 51 (1): 83-86.

Voigt, C. C., K. L. Phelps, L. Aguirre et al. 2016. Bats and buildings: the conservation of synanthroic bats. In: Voigt, C. C., T. Kingston (eds.). Bats in the Anthropocene: conservation of bats in a changing world. Springer International AG, Cham, 427-453. 